\section{ADDITIONAL RECORDS OF BANK SWALLOWS NESTING IN GRAVEL STOCKPILES}

Recently, five separate observations of Bank Swallows nesting in gravel stcck-piles were recorded in the Blue Jay (Vol. 19: 20-21, 84, 115), although apparently this habit had not been previously described in the literature. Two additional Bank Swallow colonies of this nature have since been seen. On June 24, 1961, I found an active colony occupying about 80 burrows in a stock-pile on Highway 20, near Gibbs, Saskatchewan. Burrows were excavated in a vertical profile about 10 feet high and 30 feet long, facing southwest. The material was mixed sand and gravel in compacted layers. About 35 burrows were observed in a stockpile near Raymore, Sask., at the junction of Highways 6 and 15 on September 26, 1961. These burrows were probably occupied during the summer, but of course no birds were present at the time. A slight and partly vertical face on the south end of this stock-pile provided a rather shaky-looking nesting site. - R. W. Nero, Regina.

\section{GREAT GRAY OWL AT SPIRIT LAKE}

A Great Gray Owl has been noted regularly this year (1961) during summer and early fall. All observations were made within a half mile along a well-travelled road. It was first noted on July 7 and 8 at a point where the road transects a wooded area. These first observations were at dusk. It was seen again on August 28, September 8, 14, and 19, thase observations being made during the day. The owl was invariably seen perched on a fence picket 20 to 50 yards from the nearest woods. At times it would remain on one perch for several hours, intently watching the overgrown tangle of grass and weeds for mice. In all instances it allowed people to come within 10 to 15 yards without showing concern. Motor traffic on the road did not disturb it. At the time of writing (October 15) lack of observations would indicate it has left the district, or perhaps, because of its docility, fallen prey to some thoughtless human.-William Anaka, Spirit Lake.

\section{INFORMATION WANTED}

HOW FAR NORTH DOES THE AVOCET BREED IN SASKATCHEWAN?-W. Earl Godfrey, Curator of Ornithology at the National Museum of. Canada, has requested information on the northern breeding limits of the American Avocet. The established breeding range extends at present to Kindersley, Edam, Saskatoon, and Yorkton. Will members who have definite breeding records (eggs or young) of avocets found in the area north of a line drawn between Kindersley, Saskatoon and Yorkton forward them as soon as possible to Frank Roy, 120 Maple Street, Saskatoon.

INFORIMATION WANTED RE: BURROWING OWL-For a study he is making of the Burrowing Owl in Saskatchewan, George Chopping would appreciate receiving information on the distribution of the species in the province, migration dates, and nest records. Please send this information to: George Chopping, Box 142, Dubuc, Sask.

\section{CHRISTMAS BIRD COUNT 1961}

In your report, list the numbers of each species seen on the one BEST DAY between December 20 and January 1 . In addition, list other species (number of individuals and date seen) between December 20 and January 1.

Send reports as soon as possible to:

Dr. Stuart Houston

2401 Hanover Ave., Saskatoon 